\title{
【書 評】 \\ Colin Read, The Life Cyclists: Fisher, Keynes, Modigliani and Friedman: Founders of Personal Finance
}

Basingstoke: Palgrave Macmillan, 2011, x + 216 pp.

本書はコーリン・リードの企画による「金 融論における偉大な思索」シリーズの第 1 作 目であり，その意味で本書だけでは必ずしも 完結した内容にはなっていない.また，4人 の経済学者を取り上げた各章が,「生い立ち」, 「時代」,「理論」,「応用」などからなる教科 書的な構成であり, 経済学説史の研究書とし ての体裁をとっているとは言えない.だが, その分だけ, 取り上げられる 4 人の経済学者 について, 興味深い関連点や比較点が明示さ れているところに本書のメリットがあると言 えよう。

本書で,「ライフサイクル論者」として取 り上げられているのは, アーヴィング・ フィッシャー, ジョン・メイナード・ケイン ズ, フランコ・モジリアニ, ミルトン・フリー ドマンの 4 人である. この後, シリーズは 「ポートフォリオ理論家」,「価格形成論者」, 「効率的市場価格論者」と続いていくことが 予定されている.

後のラインナップに予想される経済学者 は, ポートフォリオ理論の創立者であるハ リー・マーコヴィッッ, CAPM 理論のウィ リアム・シャープやジョン・リントナー, 効 率的市場仮説のユージン・ファーマといった 顔ぶれになると思われるため, 今回の 4 人が マクロ経済学者に偏っていることが逆に興味 を引くのである.

リードが彼ら 4 人を「ライフサイクル論者」 として括るのは, 市場のポートフォリオやそ れと不即不離な市場での価格形成の前提とな るのが個人のポートフォリオであり，その個
人のポートフォリオの問題を経済学的に明ら かにした経済学者だということである。 ライ フサイクル・モデルはモジリアニだが, その 前の二人はそれを準備し, 最後のフリードマ ンは現実的な影響力の面で評価されているよ うた。

まず，フィッシャーはベームーバヴェルク の利子に関する 3 つ原因を構成要素とし て, 投資機会と異時点間の無差別曲線からな る貯蓄と利子の理論を完成させた．本書の著 者は, フィッシャー自身が, ウォールストリー トで一度は成功した投資家であったこととこ うした理論的業績を暗に結び付けているよう である。 また, フィッシャーは優生学の信奉 者であったが，そうした側面もまた，フィッ シャーによる市場への絶対の信頼と結びつい ていると本書の著者は考えている.

これに対して, 論争の多い優生学を同じく 信奉していたケインズであるが, 市場が失敗 しうることを経験的に知っていた．ケインズ の体系では利子率が貯蓄と投資とを一致させ るようには機能しないため, 貯蓄が生産能力 を下回る生産水準をもたらしてしまうことが あり得る。こうしたケインズの議論は資本市 場の考え方にも大きな影響をもたらしたこと は言うまでもない.

こうしたケインズの議論を, フィッシャー によって確立された古典的な金融論と結びっ けたのが，本書の著者によれば，モジリアニ である。モジリアニは明確に個人のライフサ イクルをモデル化することで, 社会的に貯蓄 率がどのようにして決まるかを定式化するこ 
とに成功した。

フリードマンもまた, 古典的で静学的な枠 組みのなかで議論を始めたが, 彼のメンター であったフランク・ナイトが不確実性の問題 を注視したこともあって, 現実の市場の不安 定性にも着目した理論を提起した。ただし, その方向性は, 金融の暴走に対して歯止めを かけなくてはならないとするケインズやケイ ンジアンとは逆であった。すなわち，規制を 撤廃し，市場の透明性を高めることによって 市場本来の機能を発揮させることで不確実性 を低下させていくというものであったのであ る.

さて，こうしたテキスト的構成の間に散見 される興味深い論点を, 4 人それぞれの項目 から取り上げて確認してみよう。

まず，フィッシャーに関して，本書の著者 はフィッシャーの利子論を説明した後に, 実 質金利が名目金利とインフレ率との差に等し いというフィッシャー方程式を取り上げる. 家計が，インフレ率を調整した後の実質金利 に従って消費を決定するとすれば，インフレ 率は実体経済に対して中立的ではない影響を 与えることになる，古典派の経済学で所謂貨 幣の中立性が成り立つものと考えれば，フィ シャー方程式は古典派の体系に対して最初の 亀裂をもたらすものになるわけである。この 点, フィッシャーの世界で家計が名目金利に 従うのか, それとも実質金利に従うのかは, フィッシャー解釈として本質的な問題となり 得るものである.

第 2 に, 本書の著者は, フィッシャーとケ インズを繋ぐ上で, フランク・プランプトン・ ラムゼーの貯蓄理論に大きな紙幅を割いてい る. その理論はフィッシャーの利子論の最初 の拡張であった．ラムゼーは変分法を用いる ことによって，フィッシャーが 2 期間でしか 問題にできなかった効用の割引現在価值の最 大化問題を多期間に拡張することに成功し
た、本書の筆者は, ラムゼーの貯蓄理論のケ インズ理論との関係について詳しく述べては いないが, 評者は多期間での数学的な効用最 大化の現実的な不可能性を, ケインズも内容 をよく理解していたラムゼーの議論がケイン ズに示唆したと考えている.

フィッシャーもケインズも計量経済学的な デー夕分析が行われる以前に彼らの研究生活 を送った。これに対して, 戦後世代であるモ ジリアニやフリードマンはデータの示す消費 や貯蓄の変化を説明できる理論を提起しなく てはならなかった。

モジリアニが貯蓄のライフサイクル・モデ ルを開発するにあたって共同研究を行ったの は, 大学院の 1 年生であったリチャード・ブ ルームバーグとであった，MM 定理における マートン・ミラーとの共同研究の例もあり, 第 3 の論点として, この点を詳細に叙述して いることは，モジリアニ研究という面からの 本書のメリットの一つであろう.

モジリアニのライフサイクル・モデルに対 して, マクロ的消費の相対的安定性を,フリー ドマンは恒常所得から説明した。人々は恒常 所得を過去の所得の加重平均として構成する とする.こうした適応的期待の採用は, 新古 典派マクロ経済学のなかで合理的期待学派か らフリードマンが孤立していくきっかけにな るものと評者は考えている。 そのフリードマ ンの実証経済学という主張が, ケインズの父 であるジョン・ネヴィル・ケインズによって 最初に用いられた用語だというのが，本書で 興味深い第 4 の論点である. 実証経済学の主 張では, 現象の予測可能性にこそ重点が置か れる. ジョン・メイナード・ケインズとフリー ドマンの理論上の対立を超えた方法論上の近 さといったものも，その実証経済学のルーツ においても検討できるのかもしれない.

本書はこのように，理論的に見た上でも， 学説研究的に見た上でも, 必ずしも新しい内 
容を体系的に展開したものではない.しかし， 通常対立的にしか考えられない 4 人の経済学 者について,「ライフサイクル論者」という 一連の系譜で捉えたことによって見えてくる
ものがあり, それが最大のメリットとなって いると言えるだろう。

(山崎好裕：福岡大学) 